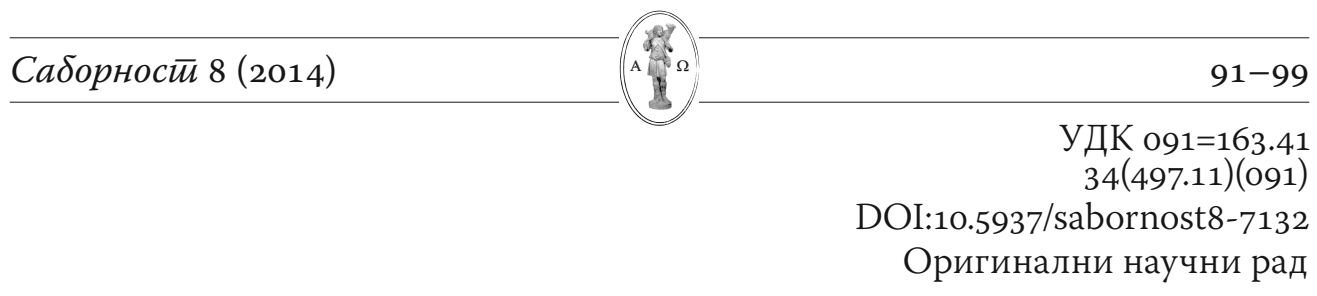

\title{
Живорад Јанковић
}

Библиотека Српске патријаршије, Београд

\section{Поводом Душановоі̄ законика}

\begin{abstract}
: Текст се у првом плану бави историјатом преписа Душановог закона, којих има преко двадесет, што је код Срба реткост. Основни проблем је у томе што од тих двадесет преписа ни два нису иста, нити иједан од њих садржи потпуни текст Законика. Популарна издања која се појављују под тим насловом су у ствари компилације створене на основу садржаја свих познатих рукописа. И кад су се правили зборници, није се много марило у каквом „друштву“ ће се наводно поштован текст наћи.
\end{abstract}

Key words: Душанов законик, рукопис, препис, Јован Рајић.

$\prod^{x}$

ушанов законик представља једино дело старе српске књижевности које својом појавом у штампаном издању (1795) одмах наилази на врло јак одјек широм тадашње учене Европе, чија последица је стални несмањени интерес опште стручне јавности кроз наредних сто година, све док не буду познати и проучени сви његови преписи. После тога, као да није учињено ништа посебно. Рађено је доста, али је све у сфери донекле познатог.

Затим, то је једино дело наше старе књижевности које је убрзо по објављивању било преведено - на самом почетку 19. века, кад ни међу тада ученим Србима није било човека који би могао у потпуности да га разуме. Извесна места у тексту Законика су и данас после толиких изучавања спорна због оскудице упоредне и основне изворне грађе (Соловјев, 1929). Преко тог превода који из поменутог разлога није могао бити ни приближно добар, дело постаје познато и доступно као снажан подстицај даљем трагању и изучавању.

Оно што га чини овом приликом привлачним није његова садржина, већ историјат његових за српске прилике бројних преписа, којих има преко двадесет, и њихова особеност је у томе што је сваки понаособ прича

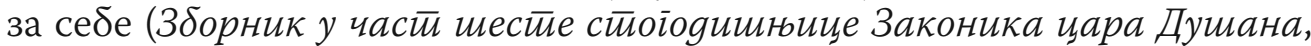
1951). Стање је такво да и после два века изучавања сваки озбиљан труд може да се оцени само као трагање за оригиналом. 
90

\section{Стојан Чиликов}

Пловдивски универзитет „Пајсије Хиландарски“, Филозофско-историјски факултет, Пловдив

\section{Св. Августин Ипонски и његови богословски ставови у вези са развојем римокатоличке мариологије}

во истраживање подвлачи најважније аспекте учења Светог Августина о Мајци Божјој. У том постављеном контексту, анализиране су и учења овог светог оца о прародитељском греху, благодати и слободној вољи, као и његова тријадологија и христологија. Овакви погледи, према ставу аутора, одговарају православном учењу о Богородици и не слажу се са каснијом средњовековном католичком мариологијом.

Key words: Свети Августин Хипонски, римокатоличка мариологија, Света Богородица, христологија, Filioque.

Датум пријема чланка: 10. 10. 2014.

Датум прихватања чланка за објављивање: 18. 11. 2014. 